\title{
Evaluación de la durabilidad de ladrillos mediante técnicas destructivas (TD) y no-destructivas (TND)
}

\author{
Evaluation of bricks durability using destructive and non- \\ destructive methods (DT and NDT)
}

\author{
G. CULTRONE ${ }^{(*)}$, M. J. DE LA TORRE ${ }^{(* *)}$, E. SEBASTIÁN ${ }^{(*)}$, O. CAZALLA ${ }^{(*)}$ \\ (*) Dpto. Mineralogía y Petrología, Univ. Granada, España \\ ${ }^{(* *)}$ Dpto. Geología, Univ. Jaén, Linares, España
}

Fecha de recepción: 3-VII-02

Fecha de aceptación: 25-IX-02

ESPAÑ

RESUMEN

Se ha estudiado el comportamiento físico-mecánico de ladrillos macizos tratados con productos consolidantes y/o hidrofugantes frente a ensayos acelerados de alteración para evaluar su durabilidad. En la fabricación de las piezas cerámicas se ha utilizado un material arcilloso rico en cuarzo y sin carbonatos al que se han añadido pequeñas cantidades de distintos aditivos (calcita, dolomita o sal). En el proceso de elaboración se han intentado reproducir ladrillos macizos similares a los empleados en muchos edificios del Patrimonio Arquitectónico. Se concluye que el uso de resina de silicona proporciona los mejores resultados, cualquiera que sea el aditivo añadido, mientras que los resultados menos satisfactorios se han calculado cuando se ha empleado una resina acrílica.

\section{SUMMARY}

We have studied the physical-mechanical behaviour of solid bricks treated with consolidants and/or water-repellents in accelerated aging tests to determine their durability. The bricks were manufactured with a quartz-rich clay lacking in carbonates to which was added small amounts of different additives (calcite, dolomite or sodium chloride). During the manufacturing process, we attempted to replicate solid bricks similar to those used in many Cultural Heritage buildings. We have concluded that silicon resin gives the best results, whatever the additive used, whereas acrylic resin gives the least satisfactory results.
PALABRAS CLAVE: ladrillos, tratamientos de conservación, productos de consolidación y protección, durabilidad

\section{INTRODUCCIÓN}

Con frecuencia se observa que los materiales de construcción de los edificios históricos y actuales se encuentran en un estado avanzado de deterioro ya que existe una fuerte agresión del ambiente cuyo origen puede ser tanto natural como procedente de la acción del hombre (1). Las intervenciones en el Patrimonio Arquitectónico pretenden no sólo frenar este detcrioro,
KEYWORDS: bricks, conservation treatments, consolidation and protection products, durability.

\section{INTRODUCTION}

It is common to see building materials in historic and modern buildings in an advanced state of decay due to environmental aggression, whether natural or induced by humans (1). Actions taken in Cultural Heritage buildings are aimed not only at slowing down 
sino tambićn ofrecer soluciones de conservación para que los materiales sean capaces de soportar esos procesos de alteración durante un período de tiempo razonable (2-5).

Ya en la antigüedad se intentaba proteger del deterioro a los edificios y a las esculturas. En aquel entonces era común sustituir las partes dañadas por otras nucvas, pero también, con frecuencia se aplicaban productos hidrofugantes, como la ccra de abeja o aceites vegetales, sobre las esculturas, incluso sobre paramentos (6-7). Fue con la llegada de la era industrial cuando se intensificó la exigencia de proteger los monumentos de las nuevas causas de deterioro, ya que la emisión de gases procedentes de las fábricas y del tráfico de automóviles aceleró de mancra notable la velocidad de los procesos de alteración. El desarrollo de la industria química proporcionó una amplia varicdad de productos consolidantes e hidrofugantes razonablemente adecuados para corregir dicho deterioro (8). Mediante la consolidación se pretende mejorar las características de cohesión y adhesión entre los diferentes granos y cristales que constituyen el material pétreo, mientras que el objetivo de la hidrofugación es disminuir la velocidad de los procesos de alteración, repeliendo el agua y con ella los productos de alteración que ésta suele llevar disueltos o en suspensión.

Se han desarrollado aún pocos trabajos sobre el uso de consolidantes o hidrofugantes en productos de arcilla cocida (9-10), además, es importante tener en cuenta la gran variabilidad de composición y microestructura de los ladrillos, incluso los procedentes de la misma fábrica, ya que productos y métodos de tratamiento válidos para ladrillos de baja porosidad no son eficaces para ladrillos con una porosidad más alta.

En este trabajo se ha pretendido evaluar, mediante el uso combinado de técnicas destructivas (TD) y nodestructivas (TND), la resistencia a su degradación en ensayos de envejecimiento acelerado de ladrillos macizos tratados con consolidantes y/o hidrofugantes. El objetivo es conocer cuáles son las variables, dependientes o no del proceso de fabricación, que incrementan la durabilidad de estos productos cerámicos. Se pretende poder determinar el nivel de alteración de estos materiales. y evaluar el grado de eficacia de un determinado producto de tratamiento, usando exclusivamente TND ya que ello permitiría extrapolar los resultados a los casos en que el uso de una TND es aconsejable (ej. in situ, en un edificio histórico).

\section{MATERIALES Y MÉTODOS}

Los ladrillos fueron preparados manualmente, siguiendo el método artesanal, a partir de una tierra deterioration, but also at offering conservation solutions so that the materials can withstand these weathering processes for a longer period of time (2-5).

As far back as Antiquity; efforts were made to protect buildings and sculptures from deterioration. At that time it was common to substitute the damaged parts by new ones, although water-repellent products such as beeswax or vegetable oils were also frequently applied to sculptures or even outer walls $(6,7)$. With the beginning of the industrial era, the need to protect monuments grew in the face of the new weathering agents, since gas emissions from factories and traffic of cars considerably accelerated aging processes. The development of the chemical industry provided a wide variety of consolidating and water-repellent products that were reasonably adequate at slowing this aging (8). The aim of consolidation products is to improve the qualities of cohesion and adhesion among the distinct grains and crystals comprising the stone. In contrast, the aim of water-repellents is to slow down the speed of weathering processes, repelling water and, with it, the salts usually dissolved or suspended in the water.

Few works have studied the use of consolidants or water-repellents on fired clay products (9-10). In addition, it should be remembered that there is considerable variation in composition and microstructure of bricks, even in ones from the same factory. This is noteworthy since, for instance, products and treatment methods valid for low-porosity bricks are not effective on high-porosity bricks.

The aim of this work has been to evaluate, using both destructive techniques (DT) and non-destructive techniques (NDT), the resistance to decay in accelerated aging tests of solid bricks treated with consolidants and/or water-repellents. The goal was to determine any variables that may increase the durability of these clay products and whether or not they' depend on the manufacturing process. We aimed to determine the degree of deterioration of the bricks and evaluate the effectiveness of certain products using exclusively NDT, which would allow us to extrapolate the results to cases where the use of NDT is advisable (eg, in situ in a historic building).

\section{MATERIALS AND METHODS}

The bricks were prepared by hand in the traditional method using a clay $(G)$ rich in quartz, and 
arcillosa $(G)$ rica en cuarzo y filosilicatos y con cantidades menores de feldespatos a la que se le añadieron otros compuestos en bajas proporciones como calcita (GC, $10 \%$ en peso), dolomita (GD, $10 \%$ en peso) o sal común (GS, $0,5 \%$ en peso), para reproducir las características tecnológicas de los ladrillos antiguos que utilizaban estos compuestos, que son productos que pueden actuar como fundentes (11). Los carbonatos han sido adicionados en polvo $(\varnothing<0,1 \mathrm{~mm})$. Por cada kilogramo de arcilla se añadieron $400 \mathrm{ml}$ de agua para hacer plástica la pasta y climinar el exceso de airc presente. La pasta cruda fuc puesta, posteriormente, en un cajón de madera humedecido con el fin de darle la forma a las piezas y revestido de arena para evitar que la pasta se adhiricra al molde. Las muestras se sacaron del molde y se dejaron secar al aire a una temperatura media de $25^{\circ} \mathrm{C}$ y una humedad relativa del $50 \%$. Cada pieza fue cocida en un horno eléctrico (marca Herotec CR-35) a temperatura de $900^{\circ} \mathrm{C}$. La temperatura se mantuvo constante una hora al alcanzar los $100^{\circ} \mathrm{C}$ y durante tres horas a la temperatura máxima establecida. La velocidad de calentamiento fue de $3{ }^{\circ} \mathrm{C} / \mathrm{min}$ aproximadamente.

El uso de carbonatos en productos cerámicos era conocido ya en la época romana dado que se solían utilizar margas carbonáticas en la producción de la "terra sigillata" (12-13). El cloruro sódico es un aditivo utilizado en la cerámica tanto por civilizaciones antiguas que se desarrollaron junto al mar (14) como por otras que vivieron en el interior del continente (15). La experiencia de estos pueblos demuestra que consiguieron mejorar con este aditivo la calidad técnica de sus productos cerámicos.

El estudio mineralógico de los ladrillos macizos se ha efectuado mediante microscopía óptica (modelo Zciss Jenapol) y difracción de rayos X (XRD, difractómetro Philips PW 1710, equipado con rendija automática). Sc ha empleado el método de polvo y las condiciones de trabajo han sido: $\mathrm{CuK} \alpha, 40 \mathrm{kV}, 40 \mathrm{~mA}, 0,12 \theta / \mathrm{s}$. La interpretación de los datos se ha llevado a cabo manualmente y mediante programas informáticos (16). La textura de las muestras ha sido estudiada mediante microscopía óptica y microscopía clectrónica de barrido (SEM), utilizando un equipo Zeiss DMS 950 que lleva incorporado un Microanálisis Link QX 2000, dotado de tensión de aceleración de $20 \mathrm{kV}$ y resolución de $5 \mathrm{~nm}$. Algunas muestras se metalizaron con oro, mientras que en otras se prefirió el recubrimiento de carbono.

Para los ensayos físicos se han utilizado probetas cortadas en cubos de $3 \mathrm{~cm}$ de arista. Sc ha estudiado el comportamicnto de las muestras sin tratar ("blanco") y tratadas con productos consolidantes $y / o$ hidrofugantes phyllosilicates and lesser amounts of feldspars. Small quantities of other additives were also included, such as calcite $(G C, 10 \% w t$.), dolomite $(G D, 10 \%$ wt.) or sodium chloride (GS, $0.5 \% \mathrm{wt}$.), in order to reproduce the technological characteristics of the ancient bricks that incorporated these minerals, which can act as melting agents (11). Carbonates were added in powder form $(\varnothing<0.1 \mathrm{~mm})$. To each kilogram of clay; $400 \mathrm{ml}$ of water was added to make the putty plastic and eliminate any excess air. The body was then moulded into bricks in a wetted wooden box coated with sand to prevent them from sticking to the mould. The samples were then removed from the mould and air-dried at an average temperature of $25^{\circ} \mathrm{C}$ and a relative humidity of 50\%. Each brick was fired in an electric oven (Herotec CR-35) at $900^{\circ} \mathrm{C}$. The temperature was kept at $100{ }^{\circ} \mathrm{C}$ for one hour and then at $900{ }^{\circ} \mathrm{C}$ for three hours. The heat was increased by approximately $3{ }^{\circ} \mathrm{C}$ per minute.

Carbonates have been added to clay products since at least the Roman period, when carbonate marls were employed in the production of "terra sigillata" (12-13). Sodium chloride was used as an additive in ceramics both by ancient civilisations that developed close to the sea (14) as well as by others that were inland (15). These peoples managed to improve the quality of their clay products with this additive.

The mineralogical study of the solid bricks was performed with light microscopy (Zeiss Jenapol) and $X$-ray diffraction (XRD, Philips PW 1710 diffractometer, equipped with an automatic slit). Powder diffraction was used and the working conditions were $C u K \alpha, 40 \mathrm{kV}, 40 \mathrm{~mA}, 0.12 \theta / \mathrm{s}$. The data were interpreted with computer programs (16). The texture of the samples was studied by light microscopy and scanning electron microscopy (SEM), using a Zeiss DMS 950 apparatus equipped with a Microanalysis Link QX 2000 with an accelerating voltage of $20 \mathrm{kV}$ and a resolution of $5 \mathrm{~nm}$. Some samples were sputter coated with gold and others were carbon coated.

The physical tests were performed with $3 \mathrm{~cm}^{3}$ samples. We studied the performance of untreated samples (blank) and of samples treated with consolidants or water-repellents (Table 1) when subjected to the 
(Tabla 1) frente a fenómenos relacionados con el movimicnto del agua en su interior. En el caso en que el producto no estuviera listo para su uso, se diluyó con disolvente orgánico (tolueno + xileno) y sucesivamente se procedió a su aplicación sobre los ladrillos. Los porcentajes de dilución elegidos se basan sobre datos previos (17). La técnica empleada fue la de la inmersión completa durante 10 minutos para favorecer una distribución más uniforme y mejor absorción de los productos por parte de las muestras a través de todas sus caras, aún sabiendo que los métodos de aplicación de estos productos en los edificios son con pincel y con pulverizador. El nivel de la solución se hizo subir gradualmente para conseguir que el aire contenido en las mucstras saliese con mayor facilidad. El secado se realizó en laboratorio durante 4 semanas, tiempo necesario para asegurar la completa polimerización de los productos. La temperatura ambiente estuvo comprendida entre 10 y $25^{\circ} \mathrm{C}$ y la humedad relativa fue del $50 \%$. Asimismo, se impidió la exxposición solar directa de las probetas durante este intervalo de tiempo.

Los productos elegidos así como la mayor parte de los existentes en el mercado reúnen los requisitos necesarios para cumplir la finalidad para la cual han sido fabricados. Sin embargo, debido a la heterogeneidad de los materiales sobre los que se aplican, no siempre alcanzan similares grados de idoneidad y eficacia.

Se determinaron las posibles variaciones del color de los ladrillos tras la aplicación de los tratamientos, ya que la variación de determinados parámetros cuantificables relacionados con cl color de un material indica una modificación estética más o menos passage of water through them. When the product to be employed was not sold ready for use, it was diluted with an organic dissolvent (toluene $+x y$ lene) and then applied on the bricks. The percentages for dilution are based on previous trials (17). The samples were completely immersed for 10 minutes to ensure a more uniform distribution and better absorption of the products through all the faces of the bricks, even though in situ application is by brush or spray gun. The solution level was raised slowly in order to allow the air trapped in the samples to escape more easily. The drying time in the laboratory was 4 weeks to ensure the complete polymerisation of the products. Room temperature was $10-25^{\circ} \mathrm{C}$ and relative humidity was $50 \%$. The samples were kept from direct sunlight during this period.

The products used, as well as most of those on the market, comply with the necessary requisites for which they were designed. However, due to the heterogeneity of the materials on which they are applied, they are not equally effective.

Possible colour variations in the bricks after application of the treatments was determined, as variations in certain quantifiable parameters related to the colour of a material can cause an aesthetic change

TABLA 1/TABLE 1

Datos de los productos empleados

(Treatments used)

\begin{tabular}{|c|c|c|c|c|}
\hline $\begin{array}{l}\text { Producto } \\
\text { Product }\end{array}$ & $\begin{array}{c}\text { Sigla } \\
\text { Acronym }\end{array}$ & $\begin{array}{l}\text { Propiedades } \\
\text { Properties }\end{array}$ & $\begin{array}{l}\text { Dilución (\%) } \\
\text { Dilution }(\%)\end{array}$ & $\begin{array}{l}\text { Composición } \\
\text { Composition }\end{array}$ \\
\hline Rurewall Coat 20 & $\overline{\mathrm{R}}$ & $\begin{array}{l}\text { Consolidante } \\
\text { Consolidant }\end{array}$ & - & $\begin{array}{l}\text { éster de sílice } \\
\text { silicic esther }\end{array}$ \\
\hline Paraloid B72 & $\mathrm{P}$ & $\begin{array}{l}\text { Consolidante } \\
\text { Consolidant }\end{array}$ & 5 & $\begin{array}{l}\text { copolímero de etilo metacrilato } \\
\text { co-polymer of ethylmethacrylate }\end{array}$ \\
\hline Tegosivin HL100 & $\mathrm{T}$ & $\begin{array}{l}\text { Hidrofugante } \\
\text { Water-repellent }\end{array}$ & 10 & $\begin{array}{l}\text { oligómero siloxano etoxifuncional } \\
\text { oligomer siloxane etoxi-functional }\end{array}$ \\
\hline Estel 1100 & $\mathrm{E}$ & $\begin{array}{l}\text { Consolidante }+ \\
\text { Hidrofugante } \\
\text { Consolidant }+ \\
\text { Water-repellent }\end{array}$ & - & $\begin{array}{l}\text { éster etílico del ácido silícico y } \\
\text { polisiloxano oligomérico } \\
\text { Ethylic esther of silicic acid and } \\
\text { oligomeric polysiloxanes }\end{array}$ \\
\hline
\end{tabular}

- diluido en disolventes orgánicos por el fabricante

- diluted in organic solvents by the manufacturer 
importante. Se utilizó un colorímetro CR-210 portátil, cuyo sistema óptico usa un árca de iluminación de $50 \mathrm{~mm}$ de diámetro. El iluminante empleado ha sido el D65 que simula una luz-día con temperatura color de $6504 \mathrm{~K}$.

Se cstableció la cantidad de agua retenida y evaporada, así como la velocidad a la que estos procesos se desarrollan mediante ensayos de absorción libre (18), desorción (19) y capilaridad (20). A partir de los valores obtenidos se han calculado la porosidad y la densidad.

Se efectuaron ensayos de envejecimiento acelerado sometiendo los ladrillos (tratados y sin tratar) a 10 ciclos de cristalización de sales, cmpleando para el ensayo una solución al $14 \%$ de $\mathrm{NaSO}_{4} \times 10 \mathrm{H}_{2} \mathrm{O}$. Se siguió la normativa UNE 7-136-58 (21) y se valoró el daño producido mediante apreciación visual de pérdida de matcrial (como paso previo al ensayo, se rotularon las aristas y vértices de las probetas), así como las posibles modificaciones del color y peso.

Entre los procedimientos que se han utilizado para determinar las propiedades físicas hay que destacar los ultrasonidos. La medida de la velocidad de propagación de ondas elásticas, $\mathrm{V}_{\mathrm{p}}$, a través de materiales de construcción constituye uno de los métodos más adecuados para su caracterización física. El método empleado ha sido cl de transmisión directa utilizando un equipo Stcinkamp BP 5, con trasductores de 100 $\mathrm{kHz}$ de frecuencia. Se efectuaron 15 medidas en cada una de las direcciones del espacio (referidas a un sistema de representación ortogonal). $V_{p 1}$ es la velocidad de las ondas longitudinales medida perpendicularmente a la dirección de compactación de la masa arcillosa, $\mathrm{V}_{\mathrm{P} 2}$ y $\mathrm{V}_{\mathrm{P} 3}$ son las velocidades según el plano de decantación de las láminas de los minerales arcillosos.

Esta técnica ha permitido, además, establecer la presencia de anisotropías, deducir el estado de porosidad/fisuración interna, detectar diferentes niveles de alteración y evaluar la variación que experimentan las muestras con la aplicación de los tratamientos de consolidación y protección, así como el daño causado por los ensayos de envejecimiento acelerado.

\section{RESULTADOS}

El estudio de la mincralogía y textura de los ladrillos mediante microscopía óptica (Figura 1) ha evidenciado la presencia como degrasante de fragmentos de esquistos con granates con textura típicamente granolepidoblástica, donde pequeñas bandas de filosilicatos se alternan con otras más grandes de cuarzo, aunque este bandeado no llega a ser marcado. that could be important. A CR-210 portable colorimeter was used, equipped with an optical system with an illuminated area $50 \mathrm{~mm}$ in diameter. Light source was D65, which simulates daylight with a temperature colour of $6504 \mathrm{~K}$.

Free absorption (18), desorption (19) and capillarity (20) assays were performed to determine the amount of water retained and evaporated, as well as the speed at which these processes took place. Porosity and density were calculated from the values thus obtained.

Accelerated aging tests were carried out by subjecting the bricks (treated and untreated) to $10 \mathrm{cycles}$ of salt crystallization, using a solution of $14 \% \mathrm{NaSO}_{4} x$ $\mathrm{IOH}_{2} \mathrm{O}$. Norm UNE 7-136-58 (21) was followed, evaluating the damage produced via a visual inspection of material loss and possible colour and weight changes. Prior to this test, the edges and corners of the samples were coloured with an indelible marker.

Ultrasound was also used, as the measurement of ultrasound elastic wave propagation $V_{P}$ through building materials is one of the best methods for determining their physical characterization. Direct transmission was employed with a Steinkamp BP 5 apparatus with $100 \mathrm{kHz}$ frequency transducers. Fifteen measurements were made lengthwise, widthwise and depthwise. $V_{P I}$ refers to the velocity of the longitudinal waves measured perpendicularly to the direction of compaction of the clay: $V_{P 2}$ and $V_{p 3}$ are the velocities along the plane of orientation of the clay minerals.

Ultrasound has also allowed us to establish the presence of anisotropies, deduce the internal state of porosity/fissuring, detect different degrees of alteration, and evaluate changes in the samples with the application of the consolidation and protection treatments, as well as the damage caused by the accelerated aging tests.

\section{RESULTS}

The study of the mineralogy and texture of the bricks by light microscopy (Figure I) has showed the presence as a temper of schist fragments with garnets having a typically granolepidoblastic texture, where small bands of phyllosilicates alternate with larger ones of quartz, although this banding is not marked. The quartz can also be found by itself in a mosaic texture and wavy 

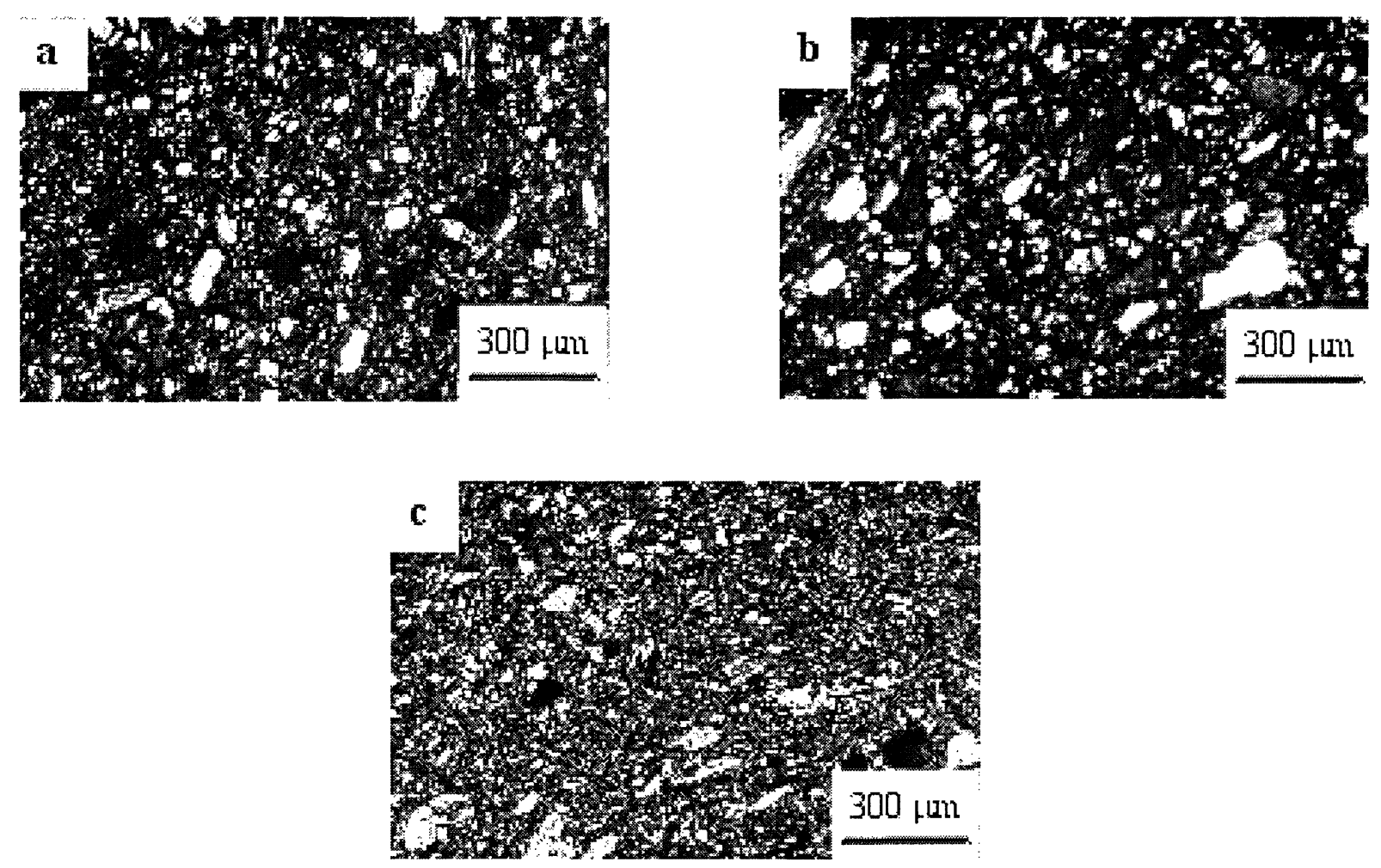

Figura 1.- Ladrillos con calcita (a), dolomita (b) y cloruro sódico (c) en los que se puede apreciar la presencia de exquistos, granos de cuarzo aislados y láminas de filosilicatos orientadas (3.2×; dos polarizadores).

Figure 1.- Bricks with calcite (a), dolomite (b) and sodium chloride (c). Note the presence of schists, isolated quartz, grains and orientated phyllosilicates (3.2x; two polarizers).

El cuarzo puede encontrarse también aislado con textura en mosaico y extinción ondulante. Finalmente, son visibles cristales de plagioclasa con maclas de tipo albita. El tamaño del degrasante no supera generalmente los $1,5 \mathrm{~mm}$. La matriz es poco birrefringente.

Los difractogramas (Figura 2) evidencian, en general, una considerable presencia de cuarzo y la persistencia de filosilicatos (fase deshidratada de la ilita) a la temperatura seleccionada de trabajo $\left(900^{\circ} \mathrm{C}\right)$. Más bajas son las concentraciones de feldespatos y hematites. En el caso en que el aditivo empleado fue el cloruro sódico, los ladrillos están ligeramente más vitrificados que los preparados con calcita o dolomita (las concentraciones de fase vítrea se han calculado mediante análisis semicuantitativo, siguiendo cl método propuesto por Hucrtas et al. (22). Se explica este hecho porque el cloruro sódico produce un descenso en la temperatura de inicio de sinterización (15). En el caso de los carbonatos, sólo cuando se ha cmpleado la dolomita se detecta la presencia de gehlenita, debido probablemente a que la dolomita empicza a descomponerse antes que la calcita (23).

Mediante observaciones realizadas a elevados aumentos por SEM se observa que en todos los casos los poros extinction. Finally; plagioclase crystals with albite-type twinned crystals are also visible. The temper size is generally under $1.5 \mathrm{~mm}$ and the matrix is only slightly: birefringent.

The diffractograms (Figure 2) generally reveal substantial amounts of quartz and the persistence of phyllosilicates (dehydrated illite phase) at the selected working temperature $\left(900^{\circ} \mathrm{C}\right)$. Feldspar and haematite concentrations are lower: Bricks prepared with sodium chloride are slightly more vitrified than those manufactured with calcite or dolomite (the vitreous phase concentrations were calculated by semiquantitative analysis, following the method proposed by Huertas et al. (22). This circumstance can be explained by the fact that sodium chloride causes a drop in the temperature for the onset of sintering (15). With the carbonates, gehlenite was detected only when dolomite was used, probably due to the dolomite beginning to decompose before calcite (23).

SEM analysis shows the pores to be subrounded and the phyllosilicates deformed and tending to join 


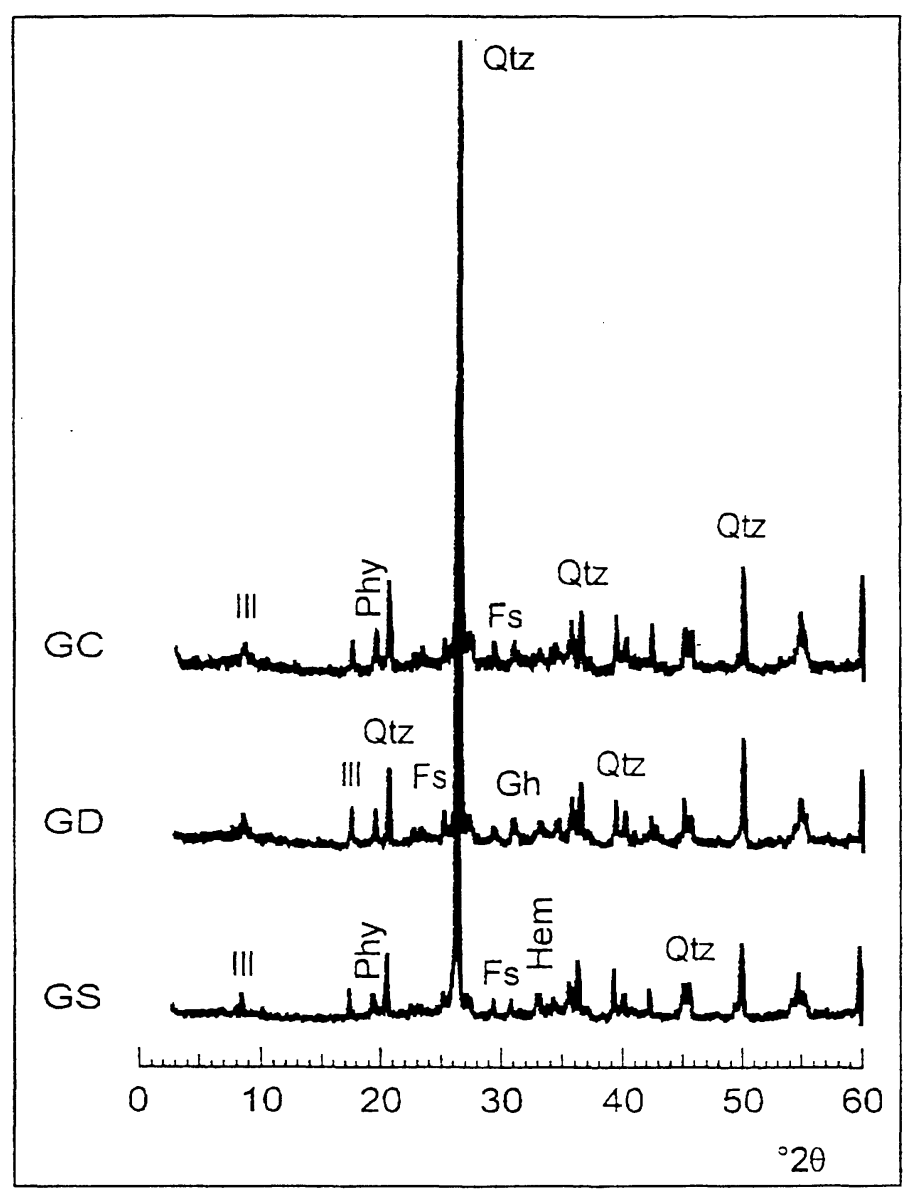

Figura 2.- Difractográmas de los ladrillos con calcita (GC), dolomita (GD) y cloruro sódico (GS) cocidos a $900{ }^{\circ} \mathrm{C}$. Leyenda (símbolos de los minerales según Kretz) (31): 111 = ilita; Phy = filosilicatos; Qtz = cuarzo; Fs = feldespatos; Gh = gehlenita; Hem = hematites

Figure 2.- Diffractograms of the bricks with calcite (GC), dolomite (GD) and sodium chloride (GS) fired at 900 "C. Legend (mineral symbols after Kretz) (3I): Ill = illite; Phy = phyllosilicates; Qtz = quartz; Fs = feldspars; $G h=$ gehlenite; Hem = haematites.

son de forma angulosa escasamente redondeados y los filosilicatos están deformados y tienden a unirse entre sí. El contacto entre las partículas es limitado y la superficie de las muestras es rugosa. Sólo en el caso de los ladrillos con cloruro sódico se aprecian indicios de vitrificación (Figura 3) como se había determinado ya por DRX.

Tras la aplicación de los tratamientos siempre se observa un aumento en peso de las probetas cerámicas (Tabla 2). Este aumento se debe a la penetración y posterior polimerización de los productos aunque el incremento de peso de las probetas depende del tipo de tratamiento aplicado.

En efecto, este parámetro varía sensiblemente si lo que se emplca es un consolidante o un hidrofugante ya que tienen características diferentes. Es evidente (Tabla 2) que la cantidad de Paraloid B72 (máximo incremento de peso del $1.36 \%$ ) que se introduce en el interior de las probetas es relativamente baja. También, se observan incrementos bajos en los ladrillos tratados con Tegosivin HL100. Los valores más altos se advierten en together: Contact between particles is limited and the sample surface is rough. Only the bricks with sodium chloride show signs of vitrification (Figure 3), as also determined by XRD.

There was an increase in sample weight after application of the treatments (Table 2) that varied depending on the type of product applied. The increase is due to the penetration and subsequent polymerisation of the products.

The main difference can be found depending on whether a consolidant or a water-repellent is used, since they have distinct characteristics. It seems evident that the amount of Paraloid B72 (maximum weight increase of $1.36 \%$ ) penetrating the samples is relatively low' (Table 2). The bricks treated with Tegosivin HL100 also show low weight increases. The highest increases are found with Rurewall Coat 20 and Estel 1100 due 

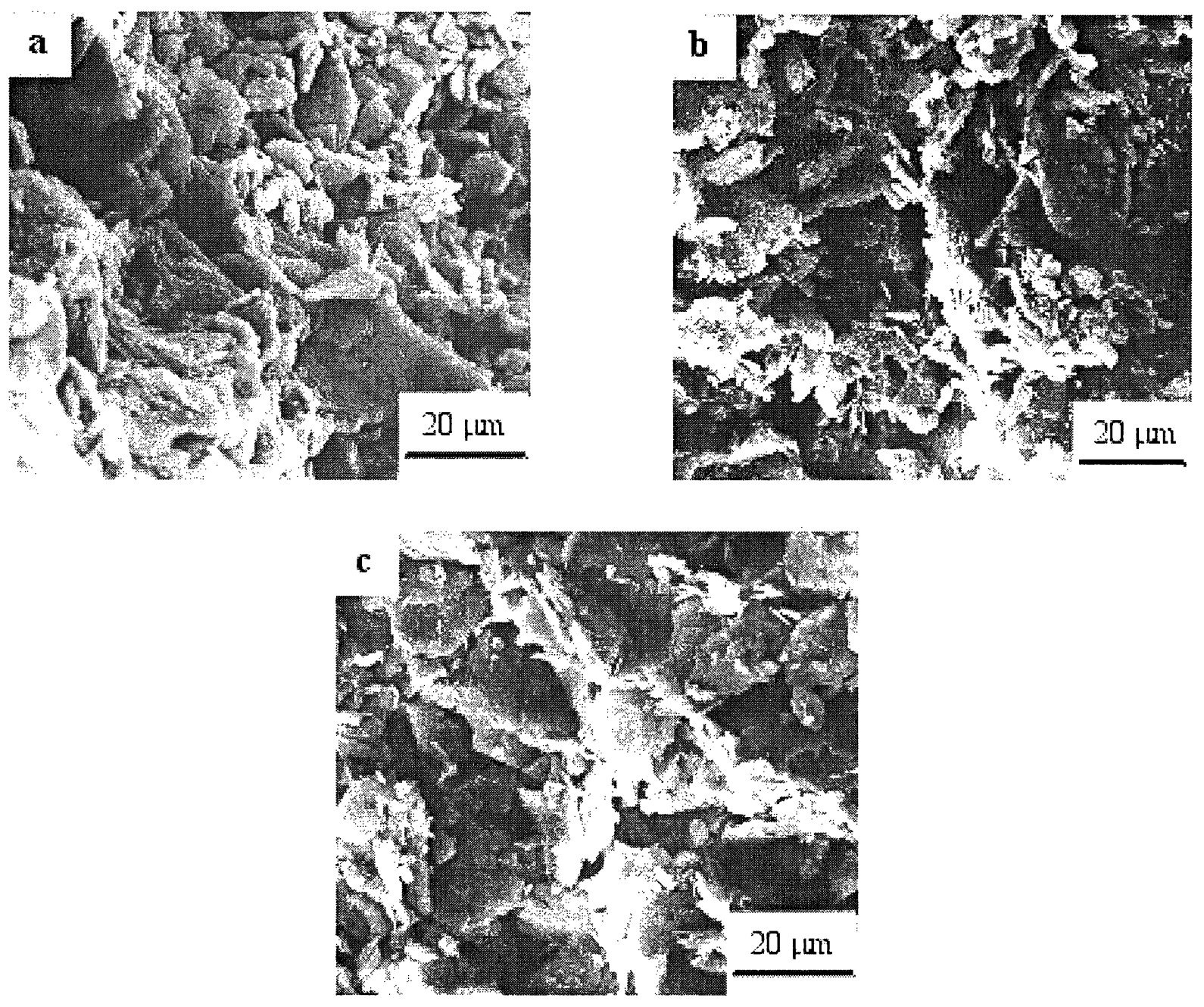

Figura 3.- Microfotografias de SEM de los ladrillos con calcita (a), dolomita (b) y cloruro sódico (c).

Figure 3.- SEM microphotographs of the bricks with calcite (a), dolomite (b) and sodium chloride (c).

TABLA 2/TABLE 2

Incremento de peso (\%) de los ladrillos después de ser sometidos a los tratamientos de consolidación y/o hidrofugación (Weight increase (\%) of bricks after consolidation and/or water-repellent treatments)

\begin{tabular}{|l|cccc|}
\hline & Rurewall Coat 20 & Paraloid B72 & Tegosivin HL100 & Estel 1100 \\
\hline GC9 & 4.11 & 1.36 & 2.55 & 6.03 \\
GD9 & 5.40 & 1.34 & 2.84 & 6.02 \\
GS9 & 6.14 & 1.14 & 2.68 & 7.05 \\
\hline
\end{tabular}

los casos del Rurewall Coat 20 y Estel 1100 no sólo debido a un mayor peso específico, sino porque penetran con mayor facilidad y en mayor cantidad.

Tras la aplicación de los tratamientos no se aprecian variaciones sensibles en el color $\left(a^{*}\right.$ y b*), ni en la luminosidad ( $\mathrm{L}^{*}$ ) de los ladrillos (Tabla 3 ).

Únicamente, disminuye ligeramente este último parámetro, pero no cambia la cromaticidad. Según la "Rock-Color-Chart" (24) las muestras pueden definirse como rojo-amarillentas. Los valores más bajos de $\mathrm{a}^{*} \mathrm{y}$ $\mathrm{b}^{*}$ se registran en los ladrillos con carbonatos. En not only to their higher specific weight, but also to the fact that they penetrate more easily and in greater amounts.

There are no noticeable changes in the colour $(a *$ and $\left.b^{*}\right)$ of the bricks after treatment application and only $a$ slight decrease in luminosity ( $\left.L^{*}\right)$, with no changes in chromaticity (Table 3). According to the "Rock-ColorChart (24), the samples can be defined as yellowishred. The lowest $a^{*}$ and $b^{*}$ values are recorded in the bricks containing carbonates since the main factor 
efecto, el principal factor en la coloración de los ladrillos sucle ser la formación de óxido de hierro (hematites). En presencia de carbonatos y a una temperatura de cocción suficientemente alta, el hierro presente puede quedar "atrapado" en la red de silicatos y aluminosilicatos de calcio y, por tanto, inhibirse la formación de hematites (25) y, en consecuencia, la cerámica presentar colores amarillentos.

Los valores de la Tabla 4 reflejan el comportamiento hídrico de las muestras "en blanco" y de las tratadas con los productos indicados. Los ladrillos preparados con $\mathrm{NaCl}$ (GS) son los que absorben menos agua debido a una mayor vitrificación de la masa tras la cocción, como se había determinado por DRX y SEM. Por otro lado, los influencing brick colour tends to be the formation of iron oxide (haematites). In the presence of carbonates and at a high enough firing temperature, the iron can be "trapped" in the silicate and calcium aluminosilicate network, thus inhibiting the formation of haematites (25) and producing a yellowish colour.

The values in Table 4 reflect the hydric behaviour of both the "blank" samples and the treated ones. Bricks prepared with $\mathrm{NaCl}(\mathrm{GS})$ absorb less water due to greater vitrification of the mass after firing, as determined by $X R D$ and SEM. The higher Af and Av values in the bricks with calcite $(G C)$ and dolomite $(G D)$ are due to the

\section{TABLA 3/TABLE 3}

Rango de variación $(\Delta)$ de las medidas de colorimetría de las probetas de ladrillos sin tratamientos (blanco) y tratadas con Rurewall Coat 20 (R), Paraloid B72 (P), Tegosivin HL 100 (T) y Estell 1100 (E). Leycnda: L* = luminosidad, a* y $\mathrm{b}^{*}=$ coordenadas cromáticas

(Range of variation ( $\Delta)$ of the colorimetry measurements of the untreated bricks (blank) and bricks treated with Rurewall Coat $20(R)$, Paraloid B72 (P), Tegosivin HL100 (T) and Estel $1100(E)$. Legend: L* =luminosity; $a^{*}$ and $b^{*}$ = chromatic coordinates $)$

\begin{tabular}{|l|ccc|}
\hline & $\Delta \mathrm{L}^{*}$ & $\Delta \mathrm{a}^{*}$ & $\Delta \mathrm{b}^{*}$ \\
\hline Blanco/Blank & $53.88-56.03$ & $18.82-20.86$ & $23.34-27.72$ \\
$\mathrm{R}$ & $49.27-55.24$ & $20.04-21.33$ & $26.17-28.57$ \\
$\mathrm{P}$ & $44.09-46.78$ & $17.35-19.00$ & $17.77-21.18$ \\
$\mathrm{~T}$ & $44.81-52.17$ & $21.27-21.69$ & $26.42-27.59$ \\
$\mathrm{E}$ & $48.80-51.06$ & $20.63-20.71$ & $24.94-26.28$ \\
\hline
\end{tabular}

\section{TABLA 4/TABLE 4}

Parámetros hídricos de los ladrillos con calcita (GC), dolomita (GD) y sal (GS), sin tratamicntos y tratadas con Rurewall Coat 20 (R), Paraloid B72 (P), Tegosivin HL100 (T) y Estel 1100 (E). Al = absorción libre (\%);

$\mathrm{Af}=$ absorción forzada $(\%) ; \mathrm{Ax}=$ grado de interconexión de los poros (\%); $\mathrm{Ca}=$ coeficiente de absorción; $\mathrm{Cd}=$ índice de desorción; $\mathrm{S}=$ cocficiente de saturación (\%); $\mathrm{Pa}=$ porosidad abierta $(\%) ; \mathrm{Pt}=$ porosidad total $(\%) ; \mathrm{D}_{\mathrm{A}}=$ densidad aparente $\left(\mathrm{g} \mathrm{cm}^{-3}\right) ; \mathrm{D}_{\mathrm{R}}=$ densidad real $\left(\mathrm{g} \mathrm{cm}^{-3}\right)$

(Hydric parameters of bricks with calcite $(G C)$, dolomite $(G D)$ and salt $(G S)$, untreated and with Rurewall Coat $20(R)$, Paraloid B72 (P), Tegosivin HL100 (T) and Estel $1100(E)$. Al = free absorption (\%); Af = forced absorption (\%);

$A x=$ degree of pore interconnection (\%); $C a=$ absorption coefficient; $C d=$ drying index; $S=$ saturation coefficient $(\%) ; P a=$ open porosity (\%); Pt = total porosity (\%); $D_{A}=\operatorname{apparent}$ density $\left(\mathrm{g} \mathrm{cm}^{-3}\right) ; D_{R}=$ real density $\left.\left(g \mathrm{~cm}^{-3}\right)\right)$

\begin{tabular}{|c|c|c|c|c|c|c|c|c|c|c|}
\hline & $\mathrm{Al}$ & Af & $\mathrm{Ax}$ & $\mathrm{Ca}$ & $\mathrm{Cd}$ & $S$ & $\mathrm{~Pa}$ & $\mathrm{Pt}$ & $\mathrm{D}_{\mathrm{A}}$ & $\mathrm{D}_{\mathrm{R}}$ \\
\hline $\mathrm{GC}$ & 24.85 & 26.17 & 5.04 & 0.1030 & 0.119 & 89.93 & 40.79 & 40.81 & 1.56 & 2.6 .3 \\
\hline GCR & 23.17 & 24.52 & 5.51 & 0.0014 & 0.111 & 22.04 & 38.00 & 39.34 & 1.60 & 2.65 \\
\hline GCP & 24.82 & 25.41 & 2.23 & 0.0282 & 0.193 & 88.98 & 39.27 & 39.83 & 1.57 & 2.61 \\
\hline GCT & 7.63 & 21.04 & 63.74 & 0.0005 & 0.219 & 19.90 & 15.46 & 33.50 & 1.59 & 2.40 \\
\hline GCE & 19.33 & 21.73 & 12.42 & 0.0043 & 0.137 & 82.67 & 33.15 & 35.80 & 1.65 & 2.57 \\
\hline GD & 24.93 & 26.35 & 5.39 & 0.0970 & 0.181 & 85.70 & 40.90 & 40.92 & 1.55 & 2.62 \\
\hline GDR & 18.79 & 20.89 & 10.05 & 0.0011 & (). 132 & 21.79 & 32.66 & 35.03 & 1.68 & 2.58 \\
\hline GDP & 22.89 & 23.22 & 1.42 & ().()051 & 0.227 & 90.94 & 38.03 & 38.37 & 1.65 & 2.68 \\
\hline GDT & 7.14 & 15.65 & 54.38 & 0.0004 & 0.180 & 42.82 & 12.20 & 23.35 & 1.49 & 1.95 \\
\hline GDE & 19.60 & 21.59 & 9.22 & 0.0043 & 0.208 & 85.46 & 34.16 & 36.37 & 1.68 & 2.65 \\
\hline$\overline{G S}$ & 22.65 & 23.75 & 4.63 & 0.0860 & 0.115 & 84.00 & 38.16 & 38.24 & 1.61 & 2.6() \\
\hline GSR & 16.25 & 19.06 & 14.74 & 0.0008 & 0.116 & 15.76 & 29.11 & 32.53 & 1.71 & 2.53 \\
\hline GSP & 22.45 & 23.06 & 2.65 & ().0241 & 0.220 & 88.59 & 37.23 & 37.87 & 1.64 & 2.64 \\
\hline GST & 8.23 & 17.01 & 51.62 & 0.0005 & 0.225 & 28.54 & 16.65 & 29.20 & 1.72 & 2.43 \\
\hline GSE & 16.37 & 17.95 & 8.80 & ().()()22 & 0.148 & 85.39 & 29.88 & 31.84 & 1.77 & 2.60 \\
\hline
\end{tabular}


valores de Al y Af más altos en los ladrillos con calcita (GC) y dolomita (GD) se deben a la descomposición de los carbonatos en $\mathrm{CaO}$ (o $\mathrm{CaO}+\mathrm{MgO}$ ), lo que crea un sistema extremadamente poroso con poros de muy pequeño tamaño (26).

En función de los productos, los valores de absorción libre (Al) son más bajos cuando se ha usado el Tegosivin HL 100 y, en orden decreciente, el Estel 1100 y el Rurewall Coat 20, con valores parecidos, y, por último, el Paraloid B72. Los valores de saturación (S) son más altos usando el Paraloid B72, llegando a ser muy parecidos a los de las muestras no tratadas. Todos los demás ladrillos tienen valores más bajos (Tabla 5). En comparación con las muestras no tratadas, se advierte que son similares los valores de densidad aparente $\left(D_{A}\right)$ y real $\left(D_{R}\right)$, mientras los valores de porosidad, tanto abierta $(\mathrm{Pa})$ como total $(\mathrm{Pt})$ son notablemente más bajos.

Observando las gráficas (Figura 4) es evidente la menor capacidad de absorber agua por parte de las muestras a las que se les ha adicionado sal (GS). Los ensayos evidencian cómo las muestras tratadas con Tegosivin HL100 son las que absorben menos agua con respecto a los demás productos. Este era un resultado previsible dadas las propiedades hidrorrepelentes de este producto. No obstante, la curva que describe el ensayo muestra un lento pero continuo incremento de peso que podría indicar una progresiva pérdida de las propiedades hidrofugantes del producto. El Rurewall Coat 20 ofrece resultados parecidos al Tegosivin hasta las 100 horas de ensayo (o bien, hasta las 200 horas en el caso de GS). Después se observa una repentina subida de los valores de absorción en todas la probetas, decomposition of the carbonates into $\mathrm{CaO}$ (or $\mathrm{CaO}+$ $\mathrm{MgO})$, which creates an extremely porous system with a very' small pore size (26).

The free absorption (Af) values, depending on the product used, vary as follows from lowest to highest: Tegosivin HL 100Estel 1100 and Rurewall Coat 20, with similar values, and, finally, Paraloid B72. The saturation $(S)$ values are highest for Paraloid B72, very close to the values for untreated samples, with the other products giving lower values (Table 5). The values of apparent density $\left(D_{A}\right)$ and real density $\left(D_{R}\right)$ are similar for treated and untreated bricks, whereas both the open porosity (Po) and total porosity (Pt) are notably lower for treated bricks.

$$
\cdots
$$

The graphs in Figure 4 clearly indicate a lower capacity of water absorption for samples containing sodium chloride (GS). The graphs also reveal that samples treated with Tegosivin HLIOO absorb the least amount of water, regardless of the additives used. This result is not unexpected since this product is a waterrepellent. Nonetheless, the curve shows a slow but continuous increase in weight that might indicate a progressive loss of water-repellent properties. Rurewall Coat 20 gives results similar to the Tegosivin up to 100 test hours, or up to 200 hours in the case of $G S$. There is then a sharp rise in the absorption values of all the samples, denoting a loss of some of the consolidant characteristics. Less performance is seen for Estel 1100 and Paraloid B72. The former, in

\section{TABLA 5/TABLE 5}

Esquema del comportamiento general de los ladrillos tratados con Rurewall Coat 20 (R), Paraloid B72 (P), Tegosivin HL100 (T) y Estel 1100 (E).

(Table of the general performance of bricks treated with Rurewall Coat 20 (R), Paraloid B72 (P), Tegosivin HL100 (T) and Estel $1100(E))$

\begin{tabular}{|l|cccccc|l|}
\hline $\begin{array}{c}\text { Producto } \\
\text { Product }\end{array}$ & $\begin{array}{c}\text { Penetración } \\
\text { Penetration }\end{array}$ & $\begin{array}{c}\text { Variación } \\
\text { del color } \\
\text { Colour } \\
\text { change }\end{array}$ & $\begin{array}{c}\text { Absorción } \\
\text { de agua } \\
\text { Water }\end{array}$ & $\begin{array}{c}\text { Desorción } \\
\text { de agua } \\
\text { Water loss }\end{array}$ & $\begin{array}{c}\text { Interconexión } \\
\text { de los poros } \\
\text { Degree of pore } \\
\text { interconnection }\end{array}$ & $\begin{array}{c}\text { Deterioro } \\
\text { Decay }\end{array}$ & $\begin{array}{c}\text { Comportamiento } \\
\text { general } \\
\text { General } \\
\text { performance }\end{array}$ \\
\hline $\mathrm{R}$ & $* * *$ & $*$ & $* *$ & $*$ & $* *$ & $* *$ & $\begin{array}{l}\text { medio-bueno } \\
\text { medium-good } \\
\text { malo } \\
\text { bad } \\
\text { bueno } \\
\text { good } \\
\text { medio-malo } \\
\text { medium-bad }\end{array}$ \\
\hline
\end{tabular}

***elevado; **intermedio; *bajo o nulo

***high; **intermediate; *low or null 


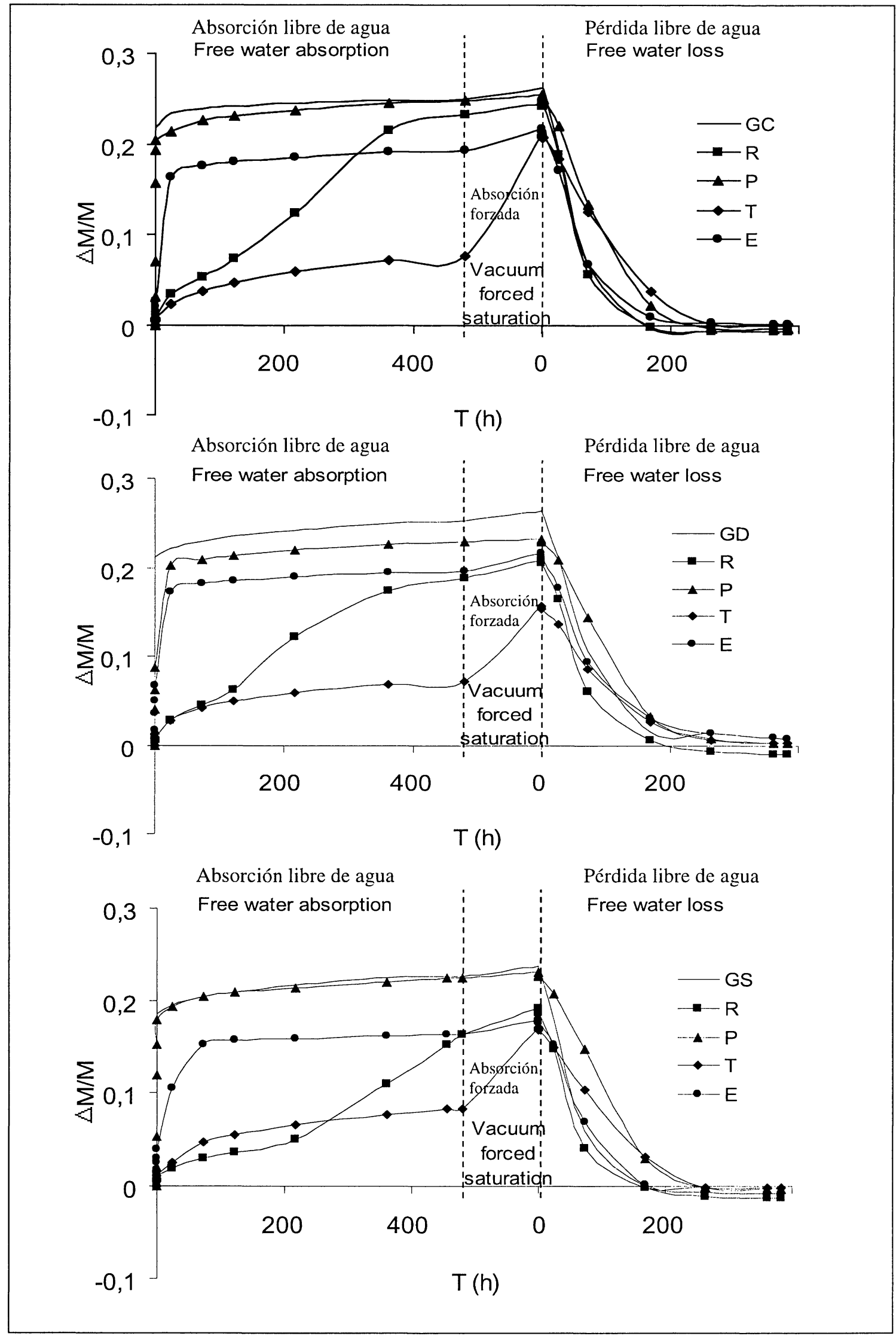

Figura 4.- Incremento de peso (en \%) por absorción libre, absorción forzada y secado de los ladrillos cocidos a 90() ${ }^{\circ} \mathrm{C}$.

Figure 4.- Weight increase (in \%) due to free absorption, forced saturation and drying of bricks fired at $900{ }^{\circ} \mathrm{C}$. 
lo que denota una pérdida de algunas características del consolidante. El peor comportamiento se aprecia en los casos del Estel 1100 y del Paraloid B72. El primero, además de ser un consolidante, es también un hidrofugante, $\mathrm{y}$, por lo tanto, presenta unos datos de absorción menores que el Paraloid. Además, se refleja una menor inclinación de la pendiente del Estel con respecto al Paraloid en todos los ensayos de absorción libre de agua.

Una vez alcanzado el valor máximo de absorción libre de agua (Al), las muestras han sido sometidas a absorción forzada (Af) saturándolas al vacío, antes de medir la desorción. Es evidente, cl mayor incremento de absorción adquirido tras este ensayo por las muestras tratadas con Tegosivin. Para evidenciar con datos numéricos el grado de interconexión de los poros así como el grado de penetración de los productos, se han comparado las dos absorciones $\mathrm{Al}$ y Af. Este valor (Ax) (27) es igual a: addition to being a consolidant, is also a waterrepellent and it therefore has lower absorption values than Paraloid. In addition, Estel gives a lower slope than Paraloid in all the free water absorption assays. Once the maximum value was reached for free water absorption (Af), the samples were subjected to forced absorption in a vacuum ( $A v)$ before measuring the desorption.

The samples treated with Tegosivin clearly have the highest values for absorption after this test. The values for Al and Af have been compared to obtain numerical data on the degree of pore interconnection; this value (Ax) (27) is equal to: y está directamente relacionado con la tortuosidad del sistema poroso del material. Dado que una gran cantidad de procesos de alteración dependen de la circulación del agua en el interior del material (28), este parámetro es de suma importancia para evaluar su durabilidad. A medida que disminuye la facilidad de comunicación entre los poros, aumenta la diferencia entre Af y Al. Los valores más altos se observan efectivamente en las muestras tratadas con Tegosivin HL100 (Tabla 4) debido a sus propiedades hidrorepelentes (en ningún caso se encuentran por debajo del $50 \%$ ), mientras los valores más bajos se han obtenido con el Paraloid B72. Este hecho confirma su mínima penetrabilidad en las probetas.

En cuanto a la velocidad de desorción del agua por los ladrillos (Figura 4) destacan las muestras tratadas con Tegosivin HL100, dado que son las más lentas en absorber el agua (parámetro Ca en la Tabla 4) pero son también las más lentas en perderla (Cd). Los ladrillos a los que se han aplicado los otros productos muestran una pendiente más acusada, es decir, un secado más rápido, aunque siempre menos acentuada que la de las muestras en blanco.

\section{$\underline{\text { Evaluación de la durabilidad }}$}

Después de 10 ciclos de ensayo de cristalización de sales, se observan dos comportamientos (Figura 5): uno que corresponde a las mucstras preparadas con carbonatos (GC y GD) y que se caracterizan por oscilaciones en la variación del peso de las probetas, y otro, correspondiente a los ladrillos con sal (GS) que and is directly related to the tortured pathways of the porous system of the material. Since a large number of weathering processes depend on water circulation inside a material (28), this parameter is extremely important in the evaluation of durability. As the ease of transit among the pores decreases, the difference between Af and Av increases. The highest values (never under 50\%) are found in the samples treated with Tegosivin HL100 (Table 4) due to its water-repellent properties. In contrast, the lowest values occur with Paraloid B72, confirming its minimal penetration in the samples.

The water desorption speed of the bricks (Figure 4) is lowest in those treated with Tegosivin HllOO (parameter Cd in Table 4), to be expected since these samples are also the slowest to absorb water (parameter Ca). The bricks treated with the other products have a steeper slope, that is, a faster drying time, although always slower than that of untreated bricks.

\section{Durability evaluation}

After 10 cycles of salt crystallization tests, two distinct behaviours can be observed (Fig. 5). One corresponds to samples prepared with carbonates (GC and GD) and is characterized by weight variations of the samples. The second corresponds to the bricks with salt (GS), which show a progressive loss of material with each 


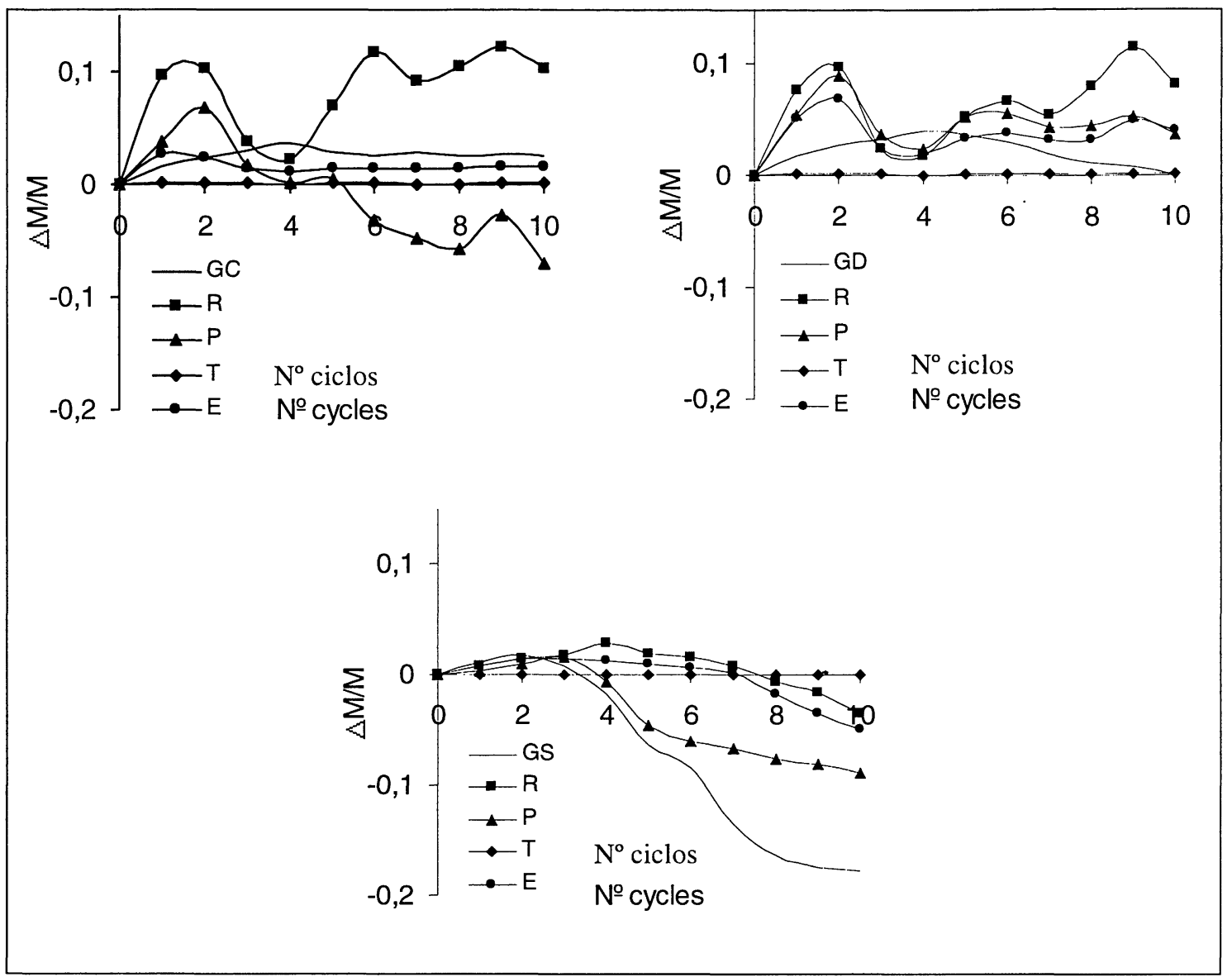

Figura 5.- Evolución de la variación de peso (en \%) de los ladrillos sometidos a ensayos de cristalización de sales.

Figure 5.- Evolution of weight variation (in \%) of the bricks subjected to salt crystallization tests.

muestran una progresiva pérdida de material según avanza el número de ciclos. La distribución irregular con picos y valles bruscos en la variación de peso se debe a la cristalización de sales en el interior de las muestras, con el consiguiente desarrollo de fracturas y a la permanencia o salida de sales de las probetas. El hecho que GS dé lugar a un diagrama diferente se debe a la ausencia de fisuras (y/o microfisuras) que son fruto de la descomposición de los carbonatos. Los resultados obtenidos únicamente en el caso del Tegosivin HL100 han sido satisfactorios: a lo largo de los 10 ciclos de ensayo las probetas muestran una evolución rectilínea del peso, lo que indica escasa o nula penetración de las sales en su interior. También el Estel 1100 proporciona resultados aceptables si son comparados con el Rurewall Coat 20 y el Paraloid B72. Se debe recordar que el Estel 1100 es un producto parcialmente hidrofugante y esa característica, sin duda, influye en el desarrollo del ensayo.

Durante varias etapas de los ensayos de envejecimiento acelerado se han realizado medidas de la velocidad de propagación de ultrasonidos en las muestras tratadas, para detectar de forma no cycle. The irregular distribution of the weight, with abrupt peaks and valleys, is due to the crystallization of salts inside the samples, with the consequent development of fractures and the continuance of the salts in the bricks or their possible escape. The GS samples produce a different diagram due to the absence of fissures (and/or microfissures) as a product of the decomposition of carbonates. The results for Tegosivin HL100 were satisfactory: throughout the 10 cycles, the samples showed a rectilinear weight evolution, indicating null or scarce penetration of salts in their interior. Estel 1100 also gave acceptable results in comparison with Rurewall Coat 20 and Paraloid B72. It should be remembered that Estel 1100 is partially water-repellent, which undoubtedly influences the results for this product.

Ultrasound wave propagation velocity was measured during several of the stages of the accelerated aging tests in order to non-destrictively determine the development and intensity of damages that might 
destructiva el desarrollo e intensidad de los daños que podían escapar a la apreciación visual. La primera medida se efectuó antes de empezar el ensayo de envejecimiento acelerado y antes de tratar las muestras con productos consolidantes y/o hidrofugantes. En los diagramas (Figura 6), esta medida corresponde al punto 1 del eje de las abscisas. Succsivamente, se midió la velocidad de ultrasonidos después de aplicar los tratamientos. Así, el punto 2 de cada diagrama indica la medida adquirida en las muestras tratadas y todavía inalteradas. Finalmente, se efectuaron tres medidas a intervalos regulares, al finalizar el tercer ciclo, el sexto y al finalizar el ensayo; en los diagramas se ven representados por los puntos 3,4 y 5 , respectivamente.

Se observa un incremento sistemático en la velocidad de ultrasonidos al pasar del punto 1 al punto 2. Esto se explica porque la absorción de productos consolidantes y/o hidrofugantes y la consecuente polimerización escape visual inspection. The first measurement was made before beginning the accelerated aging test and before treating the samples with the consolidant and/or water-repellent products. In the diagrams (Figure 6), this measurement is point 1 of the axis of the abscissas. The ultrasound wave velocity was then measured after applying the treatments and before the aging test (point 2). Finally, three measurements were made, after the third and sixth cycles and at the end of the assay (points 3, 4 and 5, respectively).

There is a systematic increase in the ultrasound wave velocity from points 1 to 2 . This rise is due to the samples becoming more compact upon absorbing the consolidant and/or water-repellent products, which

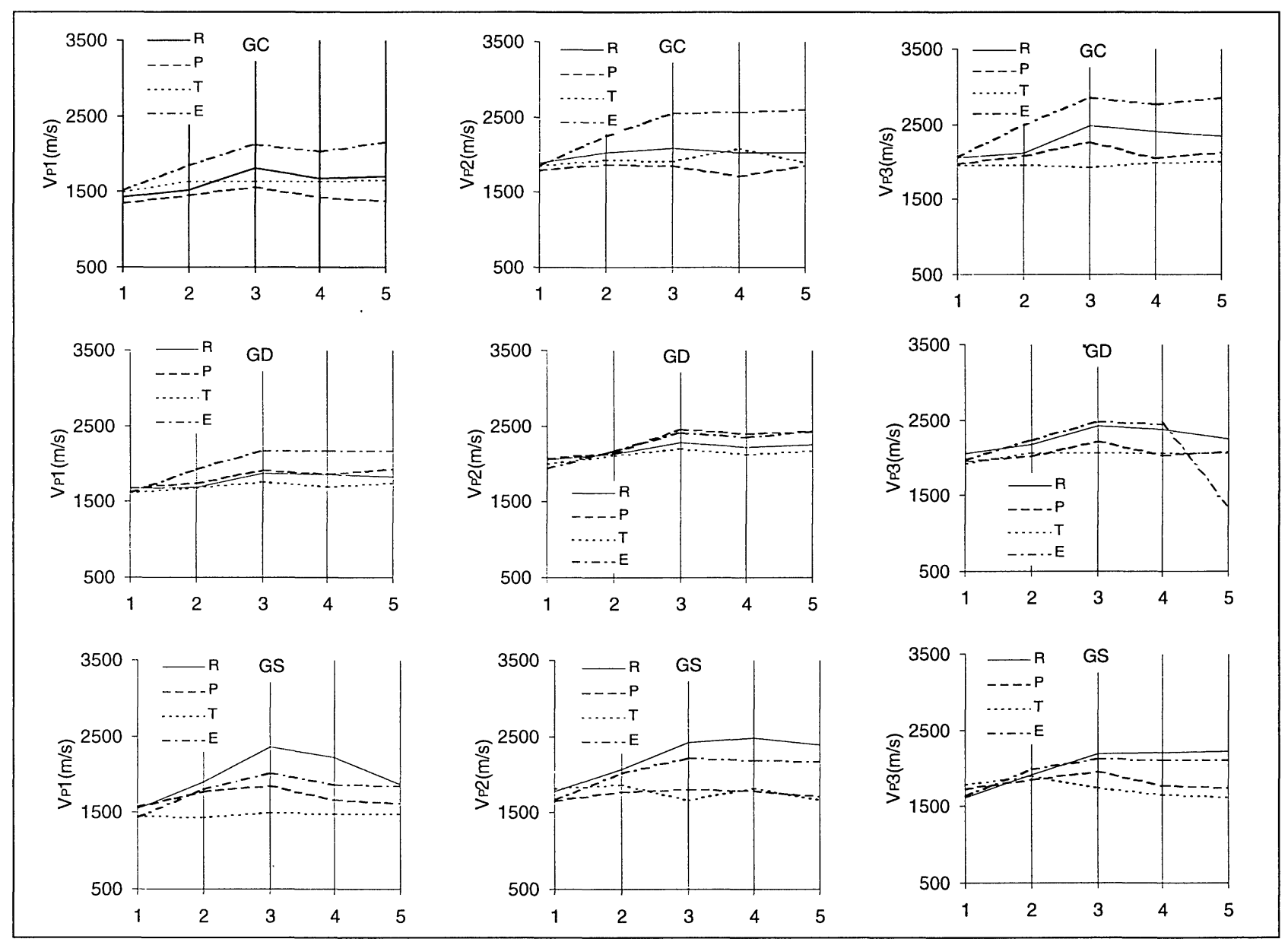

Figura 6.- Medida de la velocidad de propagación de los ultrasonidos en $\mathrm{m} / \mathrm{s}$ de los ladrillos con calcita (GC), dolomita (GD) y cloruro sódico (GS) cocidos a $900{ }^{\circ} \mathrm{C}$. En abscisa se representan las medidas efectuadas durante las siguientes etapas: $1=$ probetas sin tratamientos; $2=\operatorname{con}$ tratamientos; $3=$ después de 3 ciclos de cristalización de sales; $4=$ después de 6 ciclos; $5=$ al finalizar el ensayo de envejecimiento acelerado. $\mathrm{R}=\mathrm{Rurewall} \mathrm{Coat}$ 20; $\mathrm{P}=$ Paraloid B72; $\mathrm{T}=$ Tegosivin HL100; $\mathrm{E}=$ Estel 1100 .

Figure 6.- Measurement of ultrasound wave propagation velocity in $\mathrm{m} / \mathrm{s}$ of bricks with calcite (GC), dolomite (GD) and sodium chloride (GS) fired at $900{ }^{\circ} \mathrm{C}$. The abscissa show's the measurements taken at the following stages: $1=$ untreated bricks; $2=$ treated bricks; $3=$ after 3 salt crystallization cycles; $4=$ after 6 cycles; $5=$ at the end of the accelerated aging tests. $R=$ Rurewall Coat 20; $P=$ Paraloid B72; $T=$ Tegosivin HL100; E Estel 1100 . 
rellena los poros y fisuras dando lugar a que las probetas se vuelvan más compactas. Las muestras tratadas con Tegosivin HL100 (T) son las que menos incrementan su velocidad con respecto a las no tratadas. Esto se debe, probablemente, a la baja penetración del producto en el interior de los ladrillos. De hecho, el Tegosivin, junto al Paraloid, son los dos tratamientos que han proporcionado menores variaciones de peso tras la aplicación de los productos (Tabla 1). Además, la función de un hidrofugante es la de crear una película que impida la intrusión de agua y no está formulado para mejorar la resistencia mecánica de las muestras, favoreciendo una mayor cohesión entre las partículas. Por otra parte, el hecho de que un consolidante como el Paraloid B72 (P) aumente sólo ligeramente la velocidad de ultrasonidos, indica que su dilución en disolvente al $5 \%$ no ha sido suficiente para favorecer la penetración hacia el interior de las probetas. La aplicación de Rurewall Coat 20 (R) y el Estel 1100 (E) causan un aumento de la velocidad de ultrasonidos en los ladrillos (punto 2) indicando, por tanto, que absorben y polimerizan mayores cantidades de estos dos productos que se confirma con los datos de incremento de peso, ya comentados anteriormente.

A los tres ciclos de cristalización de sales (punto 3) se verifica un aumento muy marcado de la velocidad de ultrasonidos (excepto cuando los ladrillos están tratados con Tegosivin), debido a la cristalización del sulfato sódico rellenando poros y fisuras, mientras que las propiedades hidrófobas del Tegosivin impiden la absorción de la solución salina por parte de los ladrillos, como se había demostrado con los ensayos hídricos. En el sexto ciclo (punto 4) se verifica una reducción de la velocidad de ultrasonidos en las muestras tratadas con Rurewall, Paraloid y Estel, porque las sucesivas cristalización y disolución de las sales en su interior desarrollan fisuras en las piczas, lo que causa un nuevo aumento de la porosidad y, por tanto, una reducción de la velocidad de propagación de las ondas ultrasónicas. Finalmente, la última medida evidencia generalmente un nuevo incremento de la velocidad de ultrasonidos dado que, una vez que la capa superficial del tratamiento ha sido destruida, el sulfato de sodio puede penetrar en el interior del sistema poroso con mayor facilidad rellenándolo. Sin embargo, son visibles también casos de reducción de $\mathrm{V}_{\mathrm{p}}$, a veces acentuados como en GD cuando el producto empleado es el Estel.

Finalmente, indicar que con el microscopio electrónico de barrido (SEM) se ha podido estudiar el aspecto superficial de las muestras después del ensayo de cristalización de sales. El Tegosivin no muestra signo alguno de alteración y parece estar uniformemente distribuido en la superficie del ladrillo (Figura 7a). Totalmente opuesto es el caso del Paraloid: el producto polymerise and fill the pores and fissures. Bricks treated with Tegosivin HL100 (T) show the lowest velocity increase with respect to untreated bricks, probably due to low product penetration in the samples. In fact, Tegosivin and Paraloid showed the lowest weight changes after product application (Table 1). Moreover, the function of a water-repellent is to form a film to prevent the intrusion of water, not to improve the mechanical resistance of the samples by: enhancing particle cohesion. Furthermore, the fact that a consolidant such as Paraloid B72 (P) only slightly' increased the ultrasound wave velocity indicates that its dilution of 5\% in solvent was not enough to favour penetration deep inside the samples. The application of both Rurewall Coat $20(R)$ and Estel $1100($ E) caused an increase in the ultrasound wave velocity of the bricks (point 2), indicating that they absorb and polymerise greater amounts of these two products, as confirmed by the weight-increase data mentioned above.

After three cycles of salt crystallization (point 3), there is a marked increase in the ultrasound wave propagation velocity (except when the bricks are treated with Tegosivin), due to the crystallization of the sodium sulfate filling pores and fissures. In contrast, the hydrophobic properties of Tegosivin prevent the absorption of the saline solution by the bricks, as demonstrated in the hydric assays. After the sixth cycle (point 4), there is a decrease in the ultrasound wave propagation velocity for the samples treated with Rurewall, Paraloid and Estel. The successive cycles of crystallization and dissolution of salts inside the samples produce fissures in the pieces, which causes an increase in porosity and, therefore, a reduction in the ultrasound wave propagation velocity. Finally, the last measurement generally again shows an increase in the ultrasound velocity since, once the superficial layer of the treatment has been destroyed, the sodium sulfate can more easily penetrate deep into the porous system, filling it. However, when Estel is used, the $V_{p}$ drops, sharply in the case of $G D$.

Finally, the scanning electron microscope (SEM) was used to study the superficial appearance of the samples after the salt crystallization assays. The Tegosivin shows no signs of alteration and appears to be evenly distributed over the brick surface (Figure 7a). In stark contrast, the Paraloid does not penetrate the samples, forming instead a very superficial layer; this layer 

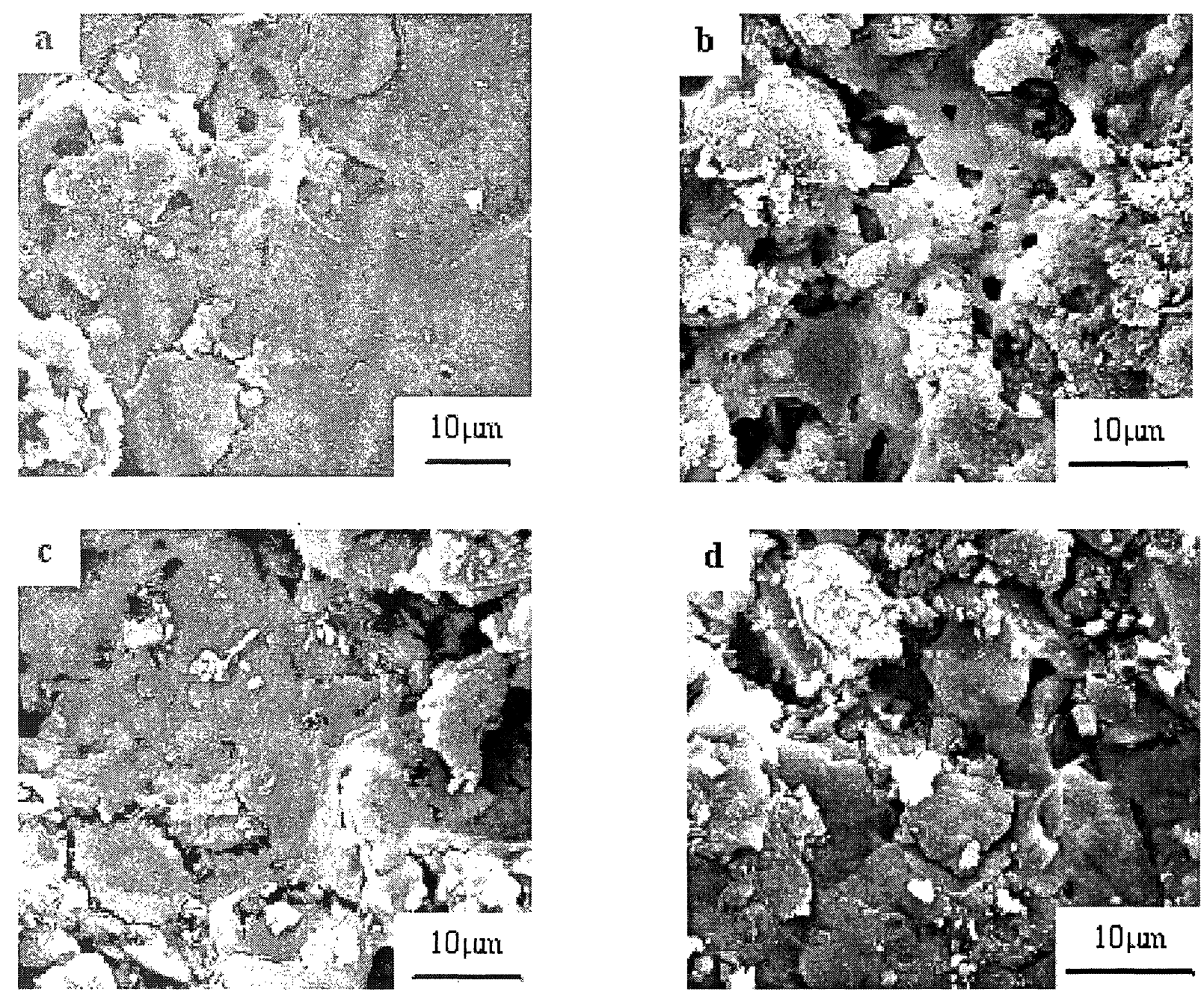

Figura 7.- Microfotografía de SEM de los ladrillos tratados con Tegosivin HL100 (a), Paraloid B72 (b), Estel 1100 (c), Rurewall Coat 20 (d) después del ensayo de envejecimiento acelerado.

Figure 7.- SEM microphotograph of bricks treated with Tegosivin HLIOO (a), Paraloid B72 (b), Estel 1100 (c), Rurewall Coat 20 (d) after the accelerated aging tests.

no ha conseguido penetrar en el interior de las muestras y se ha formado simplemente una capa muy superficial; esa capa aparece discontinua tras el ensayo de envejecimiento permitiendo la intrusión de agua y sales en el interior de los ladrillos (Figura 7b). Mejor extendida está la película de Estel, además de penetrar más que el anterior producto; se aprecian, de todas formas, algunas fisuras y despegues de fragmentos bastante limitados debido a la cristalización de sales (Figura 7c). Por último, en el caso del Rurewall Coat no se observa ninguna película continua superficial, pero las partículas constituyentes del ladrillo están perfectamente unidas las unas a las otras formando, al menos aparentemente, una masa compacta (figura 7d).

\section{CONCLUSIONES}

Los resultados experimentales han permitido llegar a las siguientes conclusiones: seems to be discontinuous after the aging test, thus allowing the passage of water and salts to the inside of the bricks (Figure 7b). The Estel film is better extended in addition to penetrating more than the Paraloid. However, there are some fissures and very limited scaling of fragments due to salt crystallization (Figure 7c). Lastly, there does not appear to be a continuous superficial coat in the case of the Rurewall Coat, but the particles comprising the bricks are perfectly bonded to one another, apparently forming a compact mass (Figure 7d).

\section{CONCLUSIONS}

The experimental results have allowed us to reach the following conclusions: 
1) La microscopía óptica, SEM y DRX han evidenciado diferencias significativas entre los ladrillos, que se resumen en un mayor grado de vitrificación cn las muestras con adición del $0,5 \%$ en peso de $\mathrm{NaCl}$ y en la formación de silicatos de calcio únicamente en los ladrillos preparados adicionándoles un $10 \%$ de carbonatos.

2) Del estudio cromático cabe destacar que no se han apreciado variaciones en el color ni en la luminosidad tras la aplicación de los productos de tratamiento, lo cual es un dato a favor de su utilización. Se ha confirmado que el uso de la colorimetría puede tener una aplicación relevante en el campo de la conservación del Patrimonio Arquitectónico, debido a su carácter no destructivo y a su potencial empleo como herramienta capaz de cuantificar la variación de color de un material de construcción al que se le ha aplicado un producto de conservación.

3) Frente a lós ensayos hídricos, el producto que mejores resultados proporciona es el Tegosivin HL 100, en cuanto reduce drásticamente el contenido en agua que pueden absorber los ladrillos, aunque en contraposición son más lentos en perderla. No alcanza los mismos resultados el Estel 1100, a pesar de ser un producto parcialmente hidrorepelente. Mcjores datos que este último se han logrado con el Rurewall Coat 20, especialmente en la primera parte del ensayo, dado que parece que sufre una pérdida parcial de sus cualidades cuando el contacto con el agua es continuo y duradero. Finalmente, sorprende negativamente el Paraloid B72 ya que no modifica las propiedades hídricas.

4) Similares resultados a los del punto 3 se observan cuando los ladrillos se someten a ensayos de deterioro acelerado. En efecto, con la aplicación del Tegosivin HL 100 las pérdidas de material son mínimas, mientras que son bastante acusadas con el Paraloid B72. Una explicación para el insatisfactorio comportamiento del Paraloid puede ser el no óptimo porcentaje de dilución del producto elegido (5\%) o bien que las características de hidrorepelencia del producto bajan sensiblemente cuando el ladrillo permanece en contacto con el agua durante un ticmpo prolongado, como ha sido citado por Charola et al. (29). Estos mismos resultados se confirman, además, mediante observaciones por SEM.

5) Finalmente, la velocidad de propagación de las ondas ultrasónicas es más alta en correspondencia con las direcciones paralelas a los planos de las láminas de los filosilicatos, orientación preferencial inducida por la preparación de las muestras $\left(\mathrm{V}_{\mathrm{P} 2} \approx \mathrm{V}_{\mathrm{P} 3}>\mathrm{V}_{\mathrm{P} 1}\right)$, con la excepción de GS donde los valores son similares para cualquier dirección y son debidos a la mayor vitrificación de estos ladrillos. En consecuencia, la adición de $\mathrm{NaCl}$ da lugar a piezas con menor
1) Light microscopy, SEM and XRD have revealed significant differences among the bricks, which can be summarised as a greater degree of vitrification in the samples with $0.5 \%$ weight $\mathrm{NaCl}$ and as the formation of calcium silicates only in the bricks prepared with $10 \%$ carbonates.

2) The chromatic study was favourable, showing no appreciable changes in colour or luminosity after the application of the treatments. We have confirmed that colourimetry can have a relevant application in the field of Architectural Heritage conservation due to its non-destructive nature and to its potential use as a tool capable of quantifying the colour changes of a building material on which a conservation product has been used.

\section{3) In the hydric tests, Tegosivin HL100 gave the best} results insofar as it drastically reduces the amount of water that can be absorbed by the bricks, although they are also slower to lose any water. The results are not as good for Estel 1100, despite it being a partially waterrepellent product. The results for Rurewall Coat 20 are better, especially in the first part of the test, since it seems to undergo a partial loss of its qualities when contact with water is continuous and long-lasting. Finally; the results for Paraloid B72 are disappointing, since the hydric properties of the bricks are unaffected by it.

4) When the bricks are subjected to accelerated aging tests, the results are similar to those in the above point. With the application of Tegosivin HL100, material loss is minimal, whereas it is quite high with Paraloid B72. One explanation for the unsatisfactory performance of Paraloid might be that the dilution rate chosen (5\%) is not optimal or that the water-repellency characteristics of the product drop sharply when the brick is in contact with water for a long time (see Charola et al.) (29). SEM observations have confirmed all the results in this point.

5) Finally, the ultrasound wave propagation velocity is higher parallel to the orientation planes of the phyllosilicates. This preferred orientation has been caused by the sample preparation $\left(V_{P_{2}} \approx V_{P_{3}}>V_{p_{1}}\right)$, with the exception of GS, where the values are similar for all directions due to the greater vitrification in these bricks. Moreover, the addition of $\mathrm{NaCl}$ produces pieces with less structural anisotropy: After treatment application, the samples with the greatest rise in $V_{p}$ are 
anisotropía estructural. Tras la aplicación de los tratamientos, las muestras que aumentan más su $\mathrm{V}_{\mathrm{p}}$ son aquellas a las que se ha aplicado Estel 1100 y Rurewall Coat 20 , ya que son productos que polimerizan en los poros de los ladrillos rellenándolos y, como consecuencia, dan lugar a una mayor compacidad. Esta técnica no destructiva se ha demostrado eficiente y precisa tanto para medir el progresivo deterioro de las muestras con el numero de ciclos del ensayo de envejecimiento, como para evaluar la eficacia de los tratamientos; por tanto, puede ser recomendada para la evaluación en situ del comportamiento de los tratamientos en muros de ladrillos.

En resumen (Tabla 5), el éster de sílice favorece una buena cohesión entre las partículas del ladrillo debido a la polimerización del gel de sílice, sin embargo, permite la entrada de agua en el interior de las muestras dado que no tiene prácticamente ningún efecto protector. $\mathrm{El}$ copolímero de etilo metacrilato ha sido el producto menos eficaz: no ha penetrado significativamente y únicamente ha conseguido consolidar de forma parcial la superficie de los ladrillos. Curiosamente se considera por algunos autores (30) una de las resinas más estables y adecuadas para la conservación de obras de arte. El ogolímero siloxano etoxifuncional, cumple perfectamente con su papel de resina hidrorrepelente, ya que la película superficial que forma impide la entrada del agua y de las sales disueltas en ella al interior de los ladrillos. Ese hecho le permite alcanzar los mejores resultados. Incluso, se puede añadir que los 10 ciclos de ensayo de envejecimiento acelerado no han sido suficientes para dañar los ladrillos tratados con este producto. El éster etílico del ácido silícico y polisiloxano oligomérico que se supone debería proporcionar la cohesión de un consolidante con la protección de un hidrofugante, no llega a alcanzar los mismos logros del ogolímero siloxano etoxifuncional. Así pues, las conclusiones de esta investigación permiten una aproximación a los criterios de selección de diferentes consolidantes e hidrofugantes en función de su composición polimérica.

\section{AGRADECIMIENTOS}

Este trabajo ha sido financiado por el Grupo de Investigación RNM179 de la Junta de Andalucía y por el Proyecto de Investigación DGI-MAT-2000-1457. those treated with Estel 1100 and Rurewall Coat 20, as these products polymerise within the brick pores, filling them and, consequently, producing greater compactness. This non-destructive technique has proven to be effective and accurate both for measuring the progressive deterioration of the samples with the number of accelerated aging test cycles as well as for evaluating the effectiveness of the treatments; it can therefore be recommended for in-situ evaluation of the behaviour of treatments on brick walls.

In summary (Table 5), silicic esther favours good cohesion among the brick particles due to the polymerisation of the silica gel. However, it allows the passage of water to the inside of the sample since it provides almost no protective qualities. Co-polymer of ethylmethacrylate is the least effective product: it shows no significant penetration and only managed to partially consolidate the brick surfaces. Curiously, some authors (30) consider it to be one of the most stable and suitable resins for the conservation of works of art. Oligomer siloxane etoxi-functional is a good water-repellent resin, as the superficial film it forms prevents the passage of water and of the salts dissolved in it into the interior of the bricks. In fact, the 10 cycles of accelerated aging were not enough to damage the bricks treated with this product. Ethylic esther of silicic acid and oligomeric polysiloxanes, which is supposed. to provide the cohesion of a consolidant and the protection of a water-repellent, does not achieve the same results as oligomer siloxane etoxi-functional. Therefore, the conclusions of this research allow an approach to the selection criteria of different consolidant and water-repellent products for protection of bricks according to their polymeric composition.

\section{AKNOWLEDGEMENTS}

This study was financially supported by the Research Group RNM179 of the Junta de Andalucia and by the Research Proyect DGI-MAT-2000-1457. We are grateful to Christine Laurin for the assistance in translating the original text.

\section{BIBLIOGRAFÍA}

(1) R. A. Kühnel: Driving forces of rock degradation. En: Protection and Conservation of the Cultural Heritage of the Mediterranean Cities. Swets \& Zeitlinger, Lisse, 2002, pp. 11-17.

(2) P. Alessi, A. Cortesi, G. Torriano, D. Visintin: Problems connected with protection of monuments from aggressive agents. $1^{\circ}$ Simposio Internazionale: La conservazione dei monumenti nel bacino del Mediterraneo, Bari, 1989, pp. 383-387. 
(3) R. M. Esbert, M. Montoto, J. Ordaz: La piedra como material de construcción: durabilidad, deterioro y conservación. Materiales de construcción, Vol. 41, nº 221 (1991), pp. 61-71.

(4) K. A. Heathcote: Durability of earthwall buildings. Construction and Building Materials, Vol. 9 (1995), pp. 185-189.

(5) K. B. Ren, D. A. Kagi: Upgrading the durability of mud bricks by impregnation. Building and Environment, Vol. 30 (1995), pp. 433-440.

(6) L. Lazzarini, O. Salvadori: A reassessment of the formation of the patina called scialbatura. Studies in Conservation, Vol. 34 (1989), 20-26.

(7) J. M. Cabrera Garrido: Materiales de reparación: sus mecanismos de actuación y criterios de selección (limpieza y protección de fachadas). Jornadas sobre restauración y conservación de monumentos, Instituto de Conservación y Restauración de Bienes Culturales, Ministerio de Cultura (1991),pp. 89-100.

(8) L. Lazzarini, M. Laurenzi Tabasso: Il restauro della pietra. CEDAM, Padova, 1986.

(9) G. Alessandrini, R. Peruzzi: Ricerca sull'efficacia di un nuovo prodotto consolidante e protettivo applicato sui mattoni. Atti del Convegno "Il mattone di Venezia. Stato delle conoscenze tecnico-scientifiche", Venezia, 1979, pp. 409-424.

(10) M. Bartolini, M. P. Nugari: Resistance to biodeterioration of some products used for rising damp barrier. En: Protection and Conservation of the Cultural Heritage of the Mediterranean Cities. Swets \& Zeitlinger, Lisse, 2002, pp. 397-400.

(11) W. D. Kingery: Introduction to ceramics. John Wiley \& Sons. New York, 1960.

(12) T. Peters, R. Iberg: Mineralogical changes during firing of calcium-rich brick clays. Ceramic Bulletin, Vol. 57, n 5 (1978), pp. 503-509.

(13) J. Mª Rincón, M. Romero: Archaeometric characterization of "Terra-Sigillata" ceramics from Spain. En: The Ceramics Cultural Heritage, V. Vincenzini and Faenza Eds., Faenza, Italia, 1995, pp. 325-330.

(14) O. S. Ryc: Keeping your temper under control: Materials and Manufacture of Papuan Pottery. Arch. and Phys. Anthropology in Oceania, Vol. 11, n 12 (1976), pp. 106-137.

(15) C. Stimmell, R. B. Heimann, R. G. V. Hancock: Indian Pottery from Mississippi Valley: Coping with Bad Raw Materials. En: Archaeological Ceramics, Smithsonian Institution Press, 1982, pp. 219-228.

(16) J. D. Martín Ramos: Programa de control y análisis del difractómetro de ray'os X. Dep. Leg. M-11719, 1990.

(17) E. M. Sebastián, M. J. de la Torre, O. Cazalla, G. Cultrone, C. Rodríguez Navarro: Evaluation of treatments on biocalcarenites with ultrasound. En: $6^{\mathrm{th}}$ International Conference on: Non-Destructive testing and Microanalysis for the Diagnostics and Conservation of the Cultural and Environmental Heritage, Roma, 1999, pp. 357-370.

(18) NORMAL 7/81: Assorbimento dell'acqua per immersione totale. Capacità di imbibizione. CNR-ICR, Roma, 1981.

(19) NORMAL 29/88: Misura dell'indice di asciugamento (drying index). CNR-ICR, Roma, 1988.

(20) NORMAL 11/85: Assorbimento d'acqua per capillarità. Coefficiente di assorbimento capillare. CNR-ICR, Roma, 1985.

(21) UNE 7-136-58: Estabilidad de áridos frente a disoluciones de sulfato sódico o sulfato magnésico. AENOR, Madrid, 1958.

(22) J. Huertas, F. Huertas, J. Linares: Evolución de las fases no cristalinas en cerámicas arqueológicas por DRX. Boletín de la Sociedad Española de Mineralogía, Vol. 14 (1991), pp. 71-78.

(23) R. S. Boynton: Chemistry' and Technology' of Lime and Limestone, $2^{\text {nd }}$ Ed., Wilcy, New York, 1980.

(24) E. N. Goddard, P. D. Trask, R. K. De Ford, O. N. Rove, J. T. Singewald, R. M. Querbeck: Rock-Color-Chart. The Geological Society of America, Boulder, Co. U.S.A., 1979.

(25) Y. Maniatis, A. Simopoulos, A. Kostikas: Mössbauer study of the effect of calcium content in iron oxide transformations in fired clays. Journal of the American Ceramic Society, 64 (1981), 263-269.

(26) D. D. Walker: The microscope of lime. Proceedings of the $4^{\text {th }}$ International Conference of Cement Microscopy, 1982, 21-48.

(27) G. Cultrone: Estudio mineralógico-petrográfico y físico-mecánico de ladrillos macizos para su aplicación en intervenciones del Patrimonio Histórico. Tesis Doctoral, Universidad de Granada, 2001.

(28) A. E. Charola, L. Lazzarini: Deterioration of brick masonry' caused by acid rain. American Chemical Society, 1986, $250-258$. (29) A. E. Charola, M. Laurenzi Tabasso, U. Santamaria: The effect of water on the hydrophobic properties of an acrylic resin. $\mathrm{V}^{\mathrm{th}}$ International Congress Deterioration and Conservation of Stone, Lausanne, 1985, 739-747.

(30) C. V. Hoire: Materials for conservation. Organic consolidants, adhesives and coatings. Butterworths. London, 1987.

(31) R. Kretz: Symbols for rock-forming minerals. American Mineralogist, 68 (1983), 277-279. 


\section{MATERIALES DE CONSTRUCCIÓN}

\section{Monográfico dedicado al VIDRIO EN LA CONSTRUCCIÓN}

La revista MATERIALES DE CONSTRUCCIÓN editada en el Instituto de Ciencias de la Construcción EDUARDO TORROJA, dedica un número doble $\left(\mathrm{N}^{\mathrm{os}} 242 / 243\right)$ a un solo material: El vidrio.

Haciéndose eco del creciente interés que suscitan las investigaciones e innovaciones sobre los productos derivados del vidrio, este material se trata, por primera vez en la Revista, de forma monográfica, con la amplitud que permite un número especial.

Los distintos artículos que componen este número son muestra de la gran variedad de características, propiedades y aplicaciones bajo las que se presentan los derivados del vidrio. Entre sus usos más comunes se encuentran: elementos transparentes de cerramientos, materiales estructurales en las fachadas, aislamientos de muros y cubiertas, recubrimientos de pisos y paredes, componentes de refuerzo de placas, paneles, morteros y hormigones, como material decorativo y estético. Hoy en día, el vidrio es un material indispensable en laconstrucción y su tecnología está en continua evolución para dar respuesta a la constante demanda de nuevos productos con carácter multifuncional.

En este númeroespecial se recogen trabajos de investigación originales e inéditos que cubren una temática muy diversa dentro de los materiales vítreos destinados o aplicados en construcción. Aparecen artículos relacionados con las vidrieras artísticas, los acristalamientos, los vidrios funcionales, las fibras de refuerzo, los vitrocerámicos y los porcelanatos. Los autores de estos trabajos, tanto los nacionales como los internacionales, son especialistas reconocidos en sus respectivos campos cientificos.

Los artículos que componen este número especial son:

- Procesos de alteración de las vidrieras medievales. Estudio y tratamientos de protección.

(Alteration processes of medieval stained glass windows. Study and protection treatments).

J. $\mathrm{M}^{\mathrm{a}}$ Fernández Navarro.

- El efecto de la corrosión en vidrieras coloreadas.

(The effect of corrosion of stained glass windows).

J. Leissner.

- Formulación de vidrios absorbentes del calor.

(Formulation of heat absorbing glasses).

P. Álvarez-Casariego y P. Mazón.

- Dimensionamiento de placas de acristalamiento para edificios mediante un modelo probabilístico de rotura. (A probabilistic model for failure design of glass plates in building).

A. Fernández Canteli, I. Viña y A. Bernardo Sánchez.

- Caracterización de fibras en forma de lana de roca para aislamiento obtenidas a partir de basaltos canarios.

(Characterization of fibers as rockwool for insulation obtained from canary islands basalts).

J. M. Cáceres, J. E. García Hernández y J. Ma Rincón.

- El GRC: Material compuesto de matriz inorgánica reforzado con fibras de vidrio AR.

(GRC: Composite material from an inorganic matrix reinforced with ar glass fibres).

P. I. Comino.

- Los materiales vitrocerámicos en la construcción.

(Glass-ceramic as building materials).

J. Ma Rincón y M. Romero.

- Gres porcelánico: Aplicaciones arquitectónicas, procesado y propiedades físico-mecánicas. (Porcelainized stoneware: Architectural, processing and physico-mechanical properties).

T. Manfredini, M. Romagnoli y J. Ma Rincón.

Venta de ejemplares: Distribución de Publicaciones

Instituto de Cicncias de la Construcción Eduardo Torroja

Serrano Galvache, s/n - 28033 Madrid.

Tfno.: (91) 302.04.40 - Fax: (91) 302.07.00 